Polish Cartographical Review

Vol. 49, 2017, no. 3, pp. 97-106

DOI: $10.1515 /$ pcr-2017-0008

\author{
PAWEŁ CEBRYKOW \\ Maria Curie-Skłodowska University, Lublin \\ Department of Cartography and Geomatics \\ pawel.cebrykow@poczta.umcs.lublin.pl
}

\title{
Elaboration of topographic bases for statistical maps, their contents and importance
}

\begin{abstract}
The author's objective is to present the role of base contents for a statistical map and determine its desired features which would influence optimum perception of the main contents of the map. The article consists of two main parts.

The first part discusses selection of cartographic projection. Presented recommendations could be summarized in a short conclusion that application of equal-area projections is the optimum solution. It results from the necessity of preserving correct spatial relations during the perception of the thematic map contents. It is recommended to show cartographic graticule on statistical maps, for it helps to recognize geometrical attributes of the map and plays the localizing role.

The second part of the article concentrates on the issue of selection of base contents' elements on statistical maps. Such selection depends on the method of presentation of the thematic contents of the map. Because of that the optimum contents of the map is discussed in the context of basic cartographic presentation methods, i.e. the dot method, the choropleth method, the diagram method and the isoline method. The role of base elements in the process of reading of the main contents is also underlined. It is shown that it is not only the localizing role. Including additional elements of base contents facilitates understanding of the spatial distribution of the phenomenon which is the main topic of the map.

The article encourages extension of the contents of statistical maps by additional elements of contents, which, while keeping correct spatial relations, can improve the efficiency of map use.
\end{abstract}

Keywords: statistical map, map contents, base map, cartographic presentation methods

\section{Introduction}

The author's objective is to recall the role of base contents on a statistical map and thus to determine its desired features which would influence optimum perception of the main contents of the map. This issue is important and current for several reasons. Firstly, contemporary maps, and especially statistical ones, are mostly elaborated using computer software. Its availability and ease of use turned map making into an egalitarian activity, accessible also to individuals without basic cartographic knowledge. As a result the base contents is marginalized and limited to the minimum. Secondly, lack of base contents adequate for the main topic of the map may deplete cartographic communication. Such maps have limited value as research tools, being limited to visualization of statistical data. Another reason is the necessity of accounting for geometrical features of the topographic base. These features have crucial impact on the interpretation of the map contents related to surface. Due to its limited length, the article concentrates on classical statistical maps, although contemporary technology allows to introduce many new solutions and elements, such as e.g. 3D or animation (T. Opach 2006, D. Dukaczewski 2010). Discussing them would however require a separate paper.

Why is the base map an important element of a thematic map and what role does it play in relation to the main thematic contents? What should it include to improve the communication of the contents which is the main theme of the map? This article aims to answer such questions. 
Firstly, let us determine what a base of a statistical map is. It can be defined as a map allowing presentation of spatial distribution of values of phenomena using quantitative methods of cartographic presentation ${ }^{1}$. Base has all attributes of a map, including mathematical elements such as projection, scale, cartographic graticule and selected elements of general map, such as borders, rivers and towns. These elements play orientational role and influence the understanding of spatial variation of phenomena values.

\section{Role of cartographic projection}

A.H. Robinson claimed that the duty of a cartographer is to make sure that map contents is presented on a properly edited base which would allow a full understanding of spatial relations (A.H. Robinson et al. 1988, p. 129). Therefore
Earth. In most statistical maps the priority is to preserve correct area relations. According to this condition equal-area projections are most commonly used (M. Pieniążek, M. Zych 2016). In the case of many projections, for some parts of them distortion is relatively low. Thus they can be ignored, and such projections can be used without negative consequences. This is confirmed in recommendations concerning the use of cartographic projections included in the regulation issued by the Polish Council of Ministers on 15 October 2012, which determines the rules of using systems of orthogonal plane coordinates for maps in particular scales (Rozporządzenie Rady Ministrów 2012). The requirements included in the Regulation concern mainly standard cartographic elaborations and although they are not obligatory for most maps (unofficial), their application is by all means right. Why area distortion is so undesired can

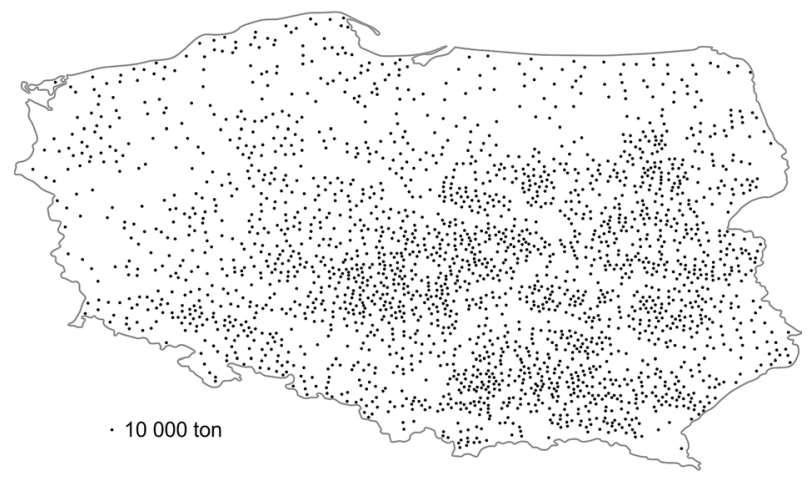

Fig. 1. Incorrectly chosen cartographic projection for the map of potato harvest in Poland results in distortion of spatial relations (on the basis of a map in the online Atlas of cartographical presentation methods, 2010-2012)

the role of cartographic base is to provide correct spatial relation of thematic contents, which means that its role is localizational. Further on it allows a reading of real relations of distribution of phenomena values. These relations must not be distorted, although this condition is not always possible to be met completely. It results from characteristics of cartographic projections used to present the surface of the

\footnotetext{
${ }^{1}$ Because of synthetic approach to the topic, quantitative cartographic methods are presented in their classic form, without their numerous varieties.
}

be clearly seen in the example of the map from figure 1 , on which harvested potato crops are presented using the dot method. The map was prepared with the cylindrical square equidistant projection, which in modest latitudes significantly distorts the area (F. Gąsiewicz 1964). At $49^{\circ}$ latitude areas are enlarged to $152.4 \%$, at $51^{\circ}$ to $158.9 \%$, and at $54^{\circ}$ they reach $170.1 \%$. Almost double enlargement affects the perception of dot density. On this map the relation of the factor to the area is respectively lowered, at the latitude of $49^{\circ}$ - to $65.6 \%$, at $51^{\circ}$ - to $62.9 \%$ and at $54^{\circ}-$ to $58.8 \%$, therefore information is distorted. 
A similar process takes place in the case of choropleth maps visualizing density index. The area of the basic field plays active role in the analysis of distribution and evaluation of the value of phenomena. For example, if two base units are assigned with the same value of population density, and the area of one of them is two times bigger, we can conclude that its population is also double of that of the smaller area.

Application of equal area projections is also reasonable when using the isoline method, with the relation similar to the one which appears in the case of the choropleth method. Because of a more difficult evaluation of phenomena value than in the case of the choropleth method, comparisons are possible only at a high level of generalization.

Another negative consequence of using bases which distort the area results from the fact that distortion is not consistent. Even on the same map we may not be able to perform proper analyses basing on dot distribution on different map parts. In the case of square equidistant projection on the area of Poland the difference of area enlargement at $49^{\circ}$ and $54^{\circ}$ reaches $11,6 \%$. Such value is significant and noticeable even during visual analysis.

The above reasoning points at the necessity of using equal-area projections preserving real area relations on statistical maps. Therefore map users should have the possibility of reading which projection they are dealing with. For this purpose cartographical graticule should be visible. It can be presented in full form, i.e. latitudes and longitudes, or reduced to node points. Reduced presentation is used when full presentation could disturb map reading.

Presenting graticule not only makes it possible to show geometric features of the map, but also to determine the location of presented phenomena. Dot maps and dasymetric choropleths are examples. In the editorial guidelines for the World Population Map ${ }^{2}$ showing graticule was one of the main recommendations (J. Siwek 1976).

\footnotetext{
2 World Population Map was conceived by Sten de Greer. His initiative was announced in Paris in 1933 during a session of the Commission of Overpopulation of the International Geographical Union. Because of the lack of statistical data it was not realized. The idea reappeared in 1956 at the IGU congress in Rio de Janeiro, where the Commission of the World Population Map was founded. In 1961 in London it announced the editing rules for the map (J. Siwek 1976).
}

Orientational significance of cartographical graticule is lower on maps edited using the choropleth or diagram methods, when phenomena values refer to commonly known areas, such as countries or administrative units which are usually easy to distinguish and identify. With different areas of reference, e.g. geographical regions or regular geometric areas, the significance of graticule is higher. A similar situation takes place when base areas are the effect of analysis of phenomena distribution, such as in the case of maps prepared using the dasymetric method.

User target is an important reason for presenting cartographic graticule. If it includes readers from different parts of the world, the significance of graticule is higher. In short, using graticule makes a map more versatile in perception.

A set of maps of the same area is an exception to the rule of using graticule on statistical maps. If at the beginning of the publication there is e.g. a general map with cartographic graticule, the following maps can be devoid of it. A good example are regional atlases which present series of statistical maps presenting various factors or changes in temporal distribution of the same phenomenon.

In summary it can be stated that visible graticule is recommended for all maps, even those with very simplified contents.

\section{Range of contents of statistical maps' bases}

The contents of a statistical map is presented on cartographic base which is most often limited to several physical elements. They usually include river network, but also settlement, road network and land cover. These elements are important for proper understanding of the distribution of phenomena values or factors being the main topic of the map. It is difficult to imagine correct reading of thematic contents without them (T. Garlej 1971, W. Żyszkowska et al. 2012). Physical elements constituting the base, similarly as in the case of graticule, play mostly localizational role. They also facilitate reading spatial relations. Unlike cartographic graticule they have yet another, crucial function; they help to analyze distribution of the phenomenon being the theme of the map. Map authors rarely 


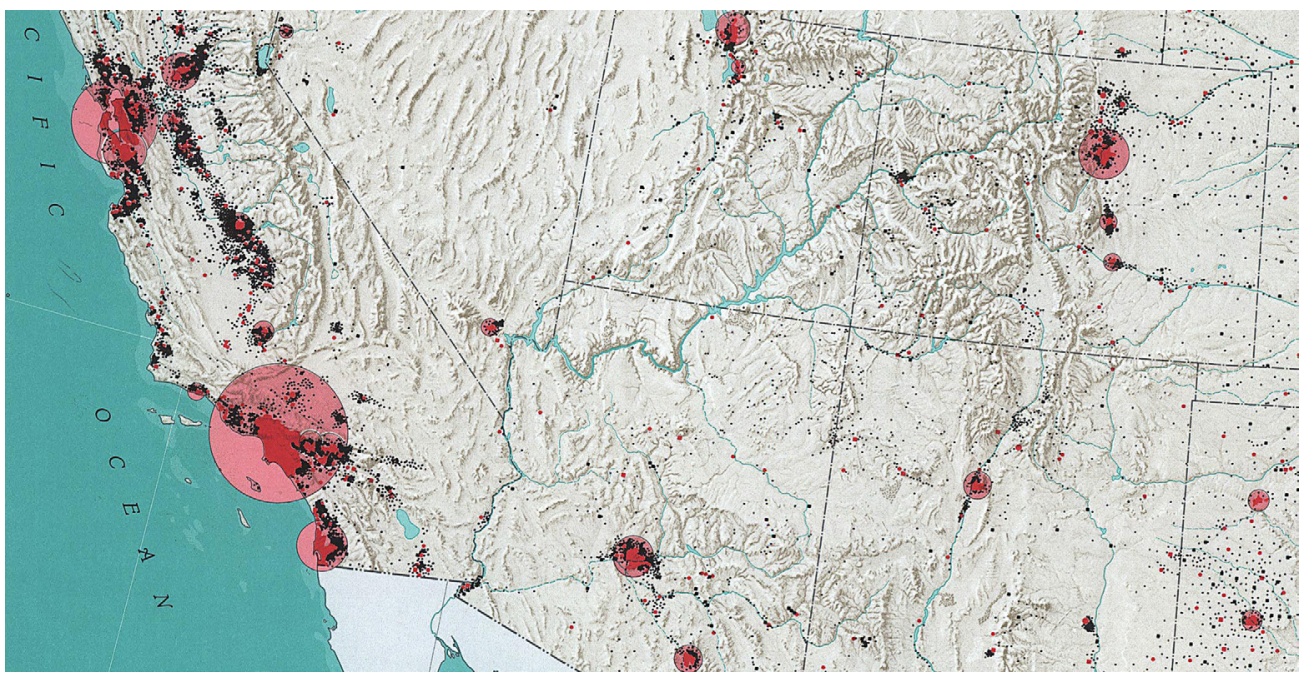

Fig. 2. A part of the dot map, or more precisely a diagram-dot map, of the population distribution in the United States. Its base contains shaded land relief, built-over areas of cities (population numbers shown in diagrams) and a relatively detailed water network; original scale 1:7,500,000, reduced by half (source: The National Atlas of the United States of America, 1970, https://www.lib.utexas.edu/maps/ national_atlas_1970.html, access 18-03-2017)

use this option, although it improves the quality of cartographic message.

Contents of a statistical map base depends on the map theme and the applied visualization method. Influence of the selected presentation method is even predominant in many cases. It is connected with the spatial reference of data, which should be consistent for proper presentation of cause-result relations. The choropleth presenting population density in Poland in regional division is an example. Presenting forests on such a map would be pointless, because population density for voivodships as averaged ratio obliterates any relations to forest location. In the above example the only possible way of looking for relation is to present forests using the choropleth method with the forest ratio referred to the same base area units. The issue defined this way can be best solved using complex choropleth map, which however goes beyond the scope of this article.

According to the thesis presented above the selection of elements of base contents depends mainly on the cartographic method used to present the main topic of the map. Thus the following description will focus on the specific features of the base in the context of the applied presentation method.

\subsection{Topographic base of a dot map}

Specific features of the base of a dot map result from the applied method of dot placement. We can distinguish the so-called topographic distribution method and the choropleth distribution method. Base for dots evenly distributed in base units should be elaborated similarly to that for a choropleth. In the case of topographic distribution of dots base construction is more complicated. Lech Ratajski pointed at the necessity of non-standard approach to the edition of bases for such maps: "A dot map requires special cartographic bases. Dot image is the main and only contents of such a map and it determines the remaining contents. Its aim is to allow interpretation of the image of dot distribution, therefore the selection of other elements must be carefully considered. They should be drawn delicately, not to overshadow the main contents of the map. Thus all descriptions which would cover dots should be omitted, and rivers as well as administrative borders should be reduced to minimum or printed in 
a different, optically weaker tint." (L. Ratajski 1989 , p. 120). The above quotation conveys the specific character of a dot map, however some issues require explanation. The statement about the influence of the base on the analysis of dot distribution is correct. The level of generalization of base elements is also important. In this case topographic distribution of dots is very important, so the base should include such elements (cities, rivers, roads) which may help to determine exactly location. Generalization of these objects may be quite strong, but it should not lead to oversimplification of the base and limiting its localizational potential. Overgeneralization can also result in topological errors.

It should also be added, that base elements not only help to localize dots, but also largely explain their distribution (J. Pasławski et al. 1997). A map "Distribution of population 1970" (fig. 2) from The National Atlas of the United States of America (1970), which includes water network, settlement and land relief, is a good example of using a well thought over base which helps to precisely localize dots and at the same time aids the analysis of their distribution. On population distribution maps land relief is often included, and visualized using various methods, from shading to hypsometry (J. Siwek 1976). It should be noted that all base map elements ought to be presented at the same level of generalization.

Summing up, it can be stated that a base for a dot map should include not only elements which facilitate distribution of dots, but also those which help to understand the distribution of the presented phenomenon.

\subsection{Topographic base of a diagram map}

Spatial reference of diagrams is decisive for the selection of base elements in the process of elaboration of diagram maps. One can distinguish diagram maps referring to a point, line or area (L. Ratajski 1989, K.A. Saliszczew 1998, J. Pasławski 2010). In the case of diagrams referring to a point or area it is necessary to place on the map the elements of the base which are points of reference for data. For point diagrams they are settlements, facilities etc. In the case of area reference they are base units in which data is collected. Also, the base with point reference can be enhanced with water or road network. The base elements of contents should be generalized to preserve their clarity, which would facilitate localization of diagrams. Diagram maps referring to base units require that these units are shown on the map. The maps with topographic base reduced to only one element significantly reduce the picture, limiting broader analysis of the phenomenon. Simplified base maps are often prepared as a result of a pragmatic approach to map edition, most of which are prepared in GIS software environment and consist in a combination of various levels of database. Such method is referred to as cartographic compilation and has been described by B. Medyńska-Gulij (2007). She has also noticed that map base does not have to be limited to base units, and although it is often treated marginally, it should enrich the context of the main topic. However, the base should not be excessively expanded, because this could lead to reversing proportions of the main contents. As a result the diagrams constituting the main theme can be less readable, and their comparison more difficult (fig. 3). Highly complicated diagrams are another example of a situation when the base should be limited to necessary contents. The more complex ones, e.g. Uhorczak's typogram should be presented on a highly generalized base.

Summing up - in the case of diagrams referring to area additional elements should be added with great care following a rule that every added element should significantly widen the scope of information. Generalization of base unit borders should be performed in such a way as to preserve their shapes and area. The first element affects unit identification, the second influences correct reading of relations between the value of a phenomenon presented with the diagram and the area of the base unit.

Generalization of the contents of bases used for presentation of linear diagrams looks slightly different. Among them one can distinguish linear diagrams, also called "ribbon" diagrams and vector diagrams (J. Pasławski 2010). The difference lies mainly in graphic form. A base map for both diagram types should contain points making it possible to determine the beginning and the end of the diagram. Ribbon diagrams also relate to such elements as roads, railroads, pipelines, etc. These objects have a particular shape, the presentation of which however is not necessary to realize the objec- 


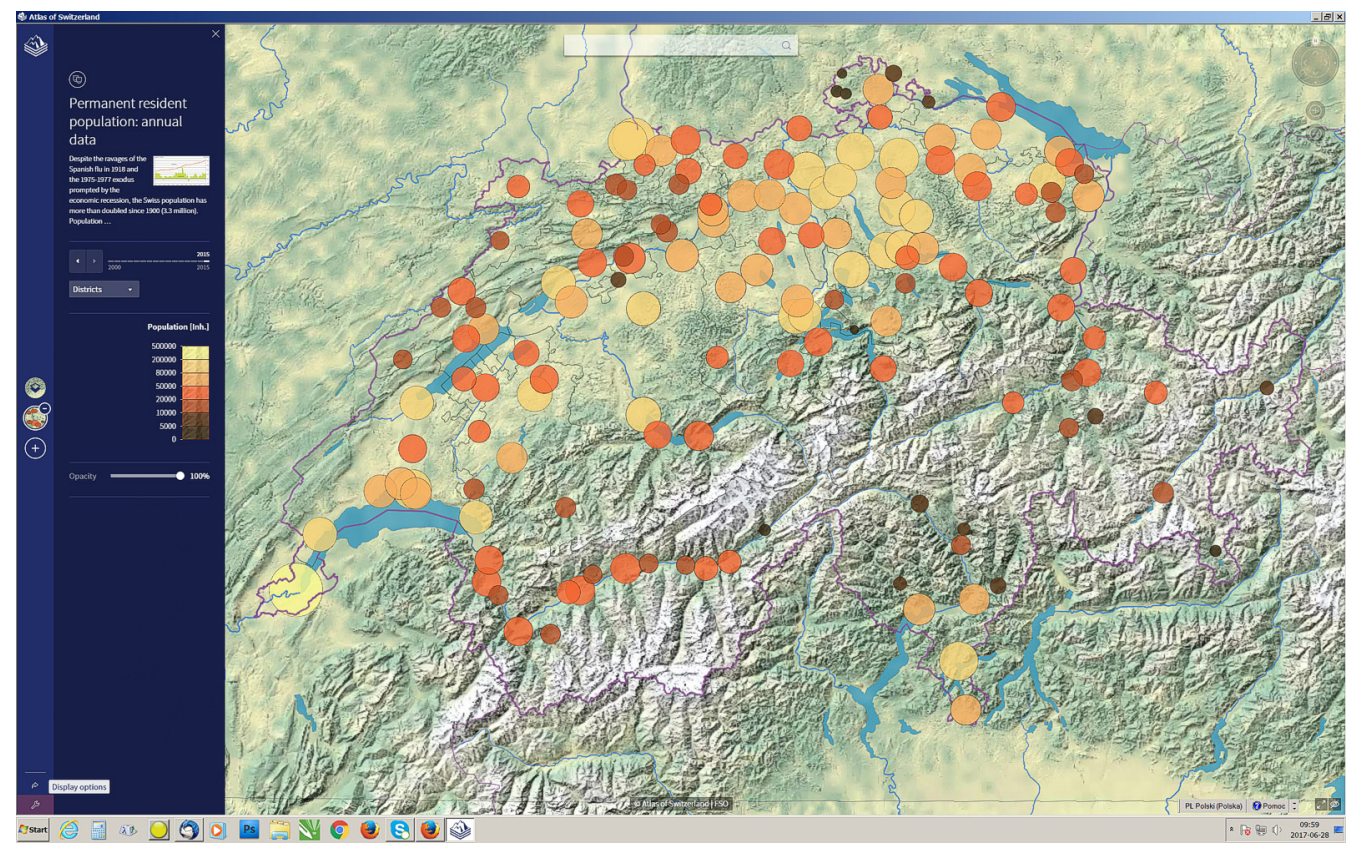

Fig. 3. Map of the population distribution of Switzerland in 2015 as an example of excessive exposure of base contents (source: Atlas of Switzerland, http://www.atlasderschweiz.ch/)

tive of the map. Because of that such lines often undergo strong generalization, the limit of which is a section of a straight line (vector). The necessity of generalization of such lines in some cases results from the lack of possibility of superimposing of the diagram.

In the case of especially wide of diagrams, it is impossible to superimpose them on the actual line on map, which necessitates its generalization.

\subsection{Topographic base of a choropleth map}

Choropleth maps are original in the sense that they present averaged value of the phenomenon or indexes referring to a base space unit. It is therefore an aeral method, in which the base unit is filled with color or pattern, according to the intensity of phenomenon (J. Pasławski 1992b, 1998). The base plays mainly orientational role, allowing reading of the whole area of the map, and further helping to distinguish types of base units. Thus borders of base units are a necessary component of the base. The base also makes it possible to identify the cartographic presentation. Omitting the information about base units may suggest that the map was prepared using the dasymetric, or even isoline method. Wrong identification of the method used can negatively affect the interpretation of the distribution of phenomenon value. The level of data aggregation is the information which is needed and which is derived from base unit distinction. It is usually included in the map title. It should also be remembered that borders of base units are the source of information about possible differences in their size and shape (fig. 4). As a result we get information about uneven level of generalization of the phenomenon at the level of base space units. In the case of choropleth maps basing on administrative division it is a fault affecting comparability of units within a map which is seemingly consistent. In Poland, for example, the biggest administrative unit (gmina) has the area almost 200 times bigger than the smallest one $^{3}$. Choropleth map users, both these who

\footnotetext{
${ }^{3}$ At regional level the smallest unit (Górowo lławeckie) has the area of 323 ha. 21 units have the area below 1000 ha, and the biggest unit (Pisz) has the area of 63,370 ha. 25 units have the area over 40,000 ha (source: General Statistical Office, for 31.12.2014).
} 


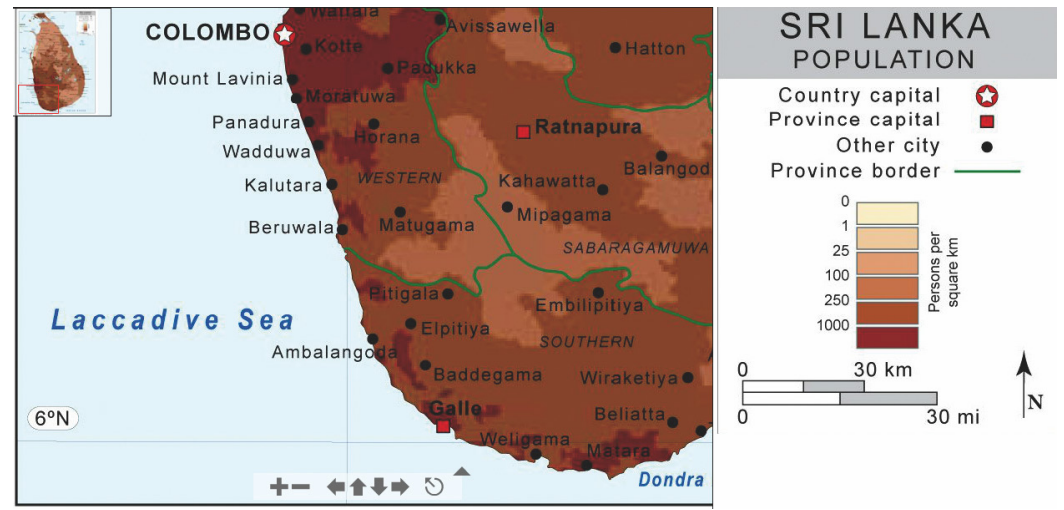

Fig. 4. Population distribution in Sri Lanka presented using a choropleth map without borders of administrative units, which are also the base units (source: http://www.stockmapagency.com/Population_Map_Sri\%20Lanka-

_C-SriL-2007-Pop.php)

prepare it and the ones who only read it, seldom realize the consequences of high disproportions of base unit sizes. Discussion on the topic of optimum base units was also conducted in Poland, taking the form of a widely organized action (J. Mościbroda 1981; E. Iwanicka-Lyrowa, J. Pasławski 1981; J. Pasławski 1992a). However, in practice it is difficult to use units of similar shape and size. Although they provide full internal comparability and improve map consistency (J. Pasławski 1992b, p. 54), they require significantly more labor. They are not commonly used because of authors' habits which have been shaped over a number of years.

Drawing of base unit borders should not be too detailed, similarly as in the case of diagram maps referring to area. However, it should be remembered that generalization should not obliterate the characteristic shape of the surface which enables unit identification. Additional elements of base contents may be presented but in practice it doesn't happen often. Sporadically one can encounter maps with added river or road network.

During the composition of choropleth map base one should preserve readability of the main contents of the map. In the case of small base units, the number of which can be high, enriching the base with additional contents is not recommended. The above recommendations refer to simple choropleth map. The situation is different in the case of dasymetric variety of the choropleth map where base units result from the distribution of the phenomenon. Such distribution is influenced by geographic environment conditions (J. Goleń, W. Ostrowski 1994), which should, if possible, be presented on the map. They include land relief, river and transportation networks, land use, etc. Of course, the above elements should undergo generalization not to obstruct the perception of the main contents of the map.

\subsection{Topographic base of an isopleth map}

Isopleth maps have methodologically a lot in common with choropleth maps. As noticed by J. Szewczuk (1975), they are an isoline interpretation of a continuous choropleth. According to L. Barwińska (1963) this type of isoline should be called an isoplethic choropleth. Similarly as in the case of choropleth the first stage is data preparation. This involves averaging of index values within base units. It is only the first stage in the procedure of isopleth map preparation. Nevertheless, there is no difference in spatial organization of data. In the case of preparing the base for an isopleth map, however, we are dealing with differences resulting from the character of the resulting surface. A choropleth map is characterized by discontinuity, while an isoline map by continuity of the statistical surface. Continuous surface is characterized by a sequence of increasing or decreasing phenomenon values. In the case of a color scale 


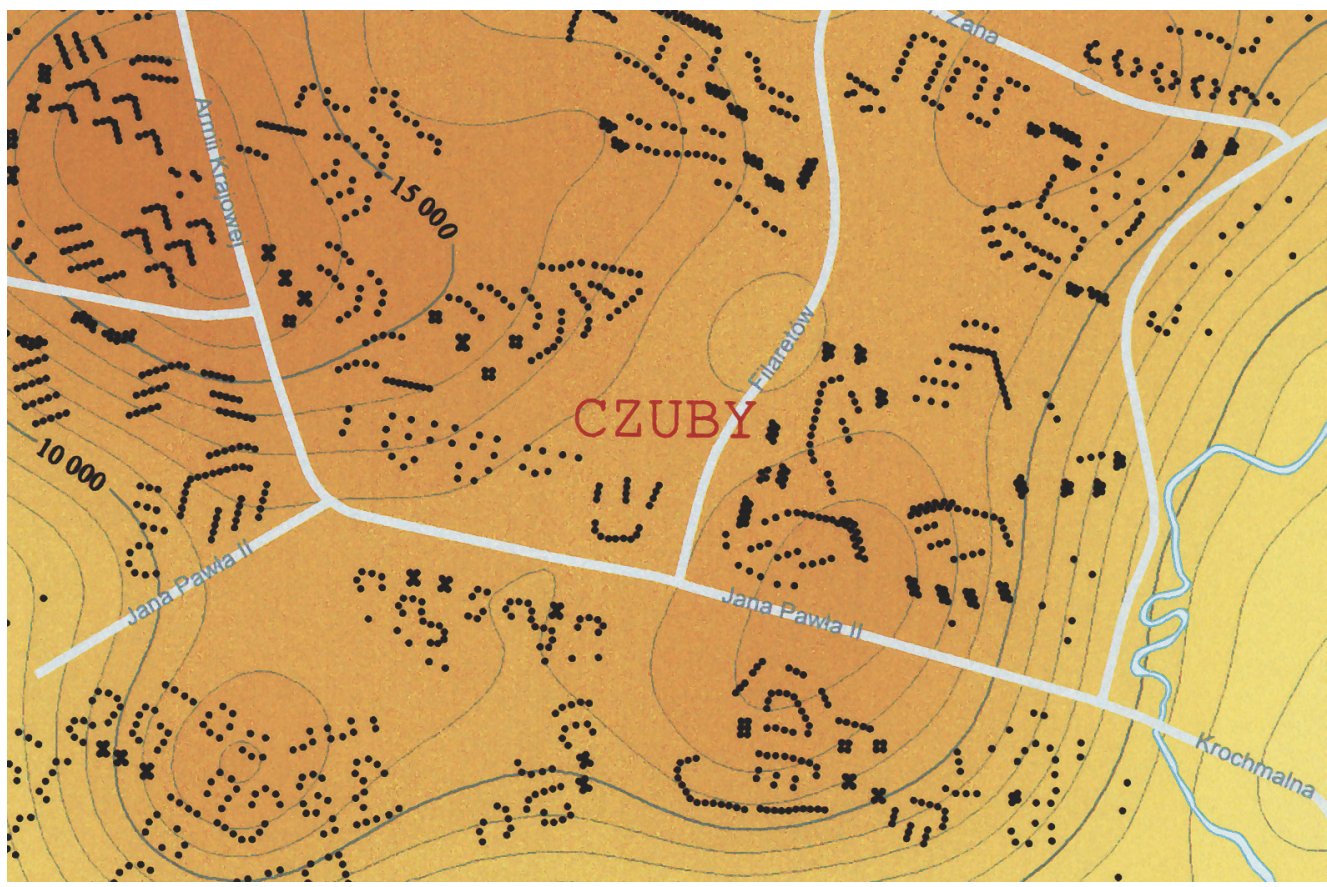

Fig. 5. A part of the isopleth map of population distribution of Lublin in 2014 with main streets which facilitate the analysis of the phenomenon (based on an M.A. thesis of T. Frąś, made at the Department of Cartography of Maria Curie-Skłodowska University in Lublin, 2005)

the change from lower to higher values results in particular colors according to the template placed in the map legend. As a result the image is organized, which increases graphic capacity of the map. Borders of base units are not necessary for correct reading of such a map, they can therefore undergo generalization. If the units represent administrative division units and support the analysis of statistical surface, it is recommended to leave the borders of units of higher order. This preserves connection with the element which is important in the analysis of phenomenon distribution. It is similar in the case of socio-economic indexes, the analysis of which and its conclusions are used in management basing on administrative division.

Physical elements, such as e.g. river networks and antropogenic objects, such as settlements and transportation network, may also appear on an isopleth map. Also in this case they facilitate correct reading of phenomenon distribution, improving spatial orientation. Such contents plays an important role in the analysis of the reasons of phenomena distribution. The level of generalization of the above elements of contents should of course be connected with map scale. In the case of large scale maps, generalization can concern qualitative aspects. Generalized road classification is an example. Generalization can also concern the quantity, concentrating e.g. on the selection of main roads constituting transportation system in a city. The network of easily recognizable main roads facilitates correct analysis of phenomenon distribution (fig. 5), and due to omitting less important streets the map becomes more legible (A. Dębowska, J. Korycka-Skorupa 2010).

Control points (with given values) may be an original element of the base of an isopleth map. Reviewers of this method saw the necessity of their placement in the map base (J. Pasławski 1992a). Possibility of complete understanding of map construction on the basis of distribution of these points, and a possibility of verification of credibility of performed interpolation was a viable argument. This view is rooted in the era before computerized interpolation methods became common, when linear interpolation 
was practically the only available method. Currently, with the availability of many complex algorithms, the necessity of placement of control points does not seem to be so obvious. Their presence informs mainly about the very fact of their use and their location. In some cases their placement is literally impossible. The method of preparation of isopleth maps by smoothing-dithering of choropleth maps is an example (P. Cebrykow 2003, 2005). In this method the number of control points regularly placed in a grid is multiplied. Presenting such a grid on a map would make it practically unreadable.

\section{Conclusions}

The base of a statistical map has many functions, although they are often marginalized by contemporary map editors, who rely use on appropriate software. Therefore it should be

\section{Literature}

Atlas metod kartograficznych, 2010-2012. Katedra Kartografii, Wydział Geografii i Studiów Regionalnych, Uniwersytet Warszawski, http://www.educarto.pl/

Barwińska L., 1963, Kartogram a mapa gęstości zaIudnienia. „Annales Universitatis Mariae-Curie Skłodowska”, Sectio B, T. 18, pp. 179-227.

Cebrykow P., 2003, Metodyka opracowywania map izopletowych z zastosowaniem procedury wygładzania kartogramu. Doctor dissertation, UMCS Lublin.

Cebrykow P., 2005, Metoda wygładzania kartogramu jako alternatywa dla tradycyjnych sposobów wykonywania map izopletowych. „Polski Przegląd Kartograficzny" T. 37, nr 1, pp. 3-12.

Dębowska A., Korycka-Skorupa J., 2010, Kartogram i kartodiagram jako przykład łączenia form prezentacji kartograficznej. „Polski Przegląd Kartograficzny" T. 42, nr 4, pp. 305-320.

Dukaczewski D., 2010, Metody projektowania animowanych kartogramów i kartodiagramów przeznaczonych do wizualizacji informacji przestrzennej za pośrednictwem geoportali. „Roczniki Geomatyki” T. 8, z. 6 (42), pp. 51-62. http://rg.ptip.org.pl/index.php/rg/article/view/RG2010-6-Dukaczewski1

Garlej T., 1971, Zagadnienie podkładów kartograficznych dla map tematycznych. In: Problemy kartografii tematycznej. Ed. F. Uhorczak. „Materiały Ogólnopolskich Konferencji Kartograficznych” T. 1, Lublin - Warszawa, pp. 178-181. stressed that the base is not only "a skeleton of the main map" but also shapes the quality of conveying the thematic contents. This can be presented in several points. Firstly, the base gives the map geometric features and thus allows to preserve proper spatial relations. Secondly, the base plays orientational role, allowing to refer thematic contents to real objects. Thirdly, it enables the analysis of a phenomenon basing on the distribution of the objects which can be in a cause-result relation with the thematic contents. Enriching the base of a map with additional contents increases the informative value of the map.

It should also be stressed that the range of contents of the base does not result from the map theme alone. It is also connected to the cartographic method used for map preparation. Therefore, it becomes obvious that bases should be individualized, concerning both the used method of presentation and the map theme.

Gąsiewicz F., 1964, Siatki na mapach. Warszawa: Państwowe Przedsiębiorstwo Wydawnictw Kartograficznych, $304 \mathrm{pp}$.

Goleń J., Ostrowski W., 1994, Metoda dazymetryczna - rys historyczny. „Polski Przegląd Kartograficzny”, T. 26, nr 1, pp. 3-17.

Iwanicka-Lyrowa E., Pasławski J., 1981, Z problematyki sieci pól znormalizowanych jako układu odniesienia badań przestrzennych. „Polski Przegląd Kartograficzny" T. 13, nr 2, pp. 66-72.

Medyńska-Gulij B., 2007, Pragmatyczne podstawy kompilowania kartograficznego. Poznań: Wydawnictwo Naukowe Uniwersytetu im. Adama Mickiewicza, $138 \mathrm{pp}$.

Mościbroda J., 1981, Problematyka pola podstawowego w badaniach geografów i kartografów polskich. „Polski Przegląd Kartograficzny” T. 13, nr 2, pp. 57-65.

Opach T., 2006, Z problematyki wykorzystania animacji w kartografii, „Polski Przegląd Kartograficzny” T. 38, nr 4, pp. 301-315.

Pasławski J., 1992a, O wiarygodności kartogramów i map izoliniowych. „Polski Przegląd Kartograficzny” T. 24, nr 1-2, pp. 17-26.

Pasławski J., 1992b, Kartogram jako forma prezentacji kartograficznej. „Rozprawy Uniwersytetu Warszawskiego” 378, Warszawa, 130 pp.

Pasławski J., 1998, Jak opracować kartogram. Warszawa: Uniwersytet Warszawski, 120 pp. 
Pasławski J., Lodzińska E., Wieczorek W., 1997, Opracowanie mapy rozmieszczenia ludności do Atlasu Rzeczypospolitej Polskiej. „Polski Przegląd Kartograficzny" T. 29, nr 3, pp. 155-161.

Pasławski J. (ed.), 2010, Wprowadzenie do kartografii i topografii. Second edition. Warszawa: Nowa Era, 416 pp.

Pieniążek M., Zych M., 2017, Mapy statystyczne. Opracowanie i prezentacja danych, Warszawa: Główny Urząd Statystyczny, 260 pp.

Ratajski L., 1989, Metodyka kartografii społeczno-gospodarczej. Second edition. Warszawa: Państwowe Przedsiębiorstwo Wydawnictw Kartograficznych, 379 pp.

Robinson A., Sale R., Morrison J.,1988, Podstawy kartografii. Warszawa: Państwowe Wydawnictwo Naukowe, 623 pp. (Polish transl. Elements of Cartography, 1978).
Rozporządzenie Rady Ministrów z dnia 15 października 2012 r. w sprawie państwowego systemu odniesień przestrzennych, 2012. „Dziennik Ustaw Rzeczypospolitej Polskiej” Nr 214, item 1247.

Saliszczew K.A., 1998, Kartografia ogólna. Second edition. Warszawa: Wydawnictwo Naukowe PWN, 308 pp. (Polish transl. Kartovedenie, 1982).

Siwek J., 1976, Zastosowanie metody kropkowej do przedstawiania rozmieszczenia ludności na przykładzie Mapy Ludnościowej Świata 1:1 000 000. „Polski Przegląd Kartograficzny” T. 8, nr 4, pp. 173-183.

Szewczuk J., 1975, Miejsce metody izarytmicznej (izopletowej) wśród metod kartograficznych. „Polski Przegląd Kartograficzny” T. 7, nr 2, pp. 49-55.

Żyszkowska W., Spallek W., Borowicz D., 2012, Kartografia tematyczna. Warszawa: Wydawnictwo Naukowe PWN, 342 pp. 